\title{
Preliminary results from a legacy indicator tool for measuring climate change related impacts on built heritage
}

\author{
Cathy Daly ${ }^{*}$ (1)
}

\begin{abstract}
Background: Gradual changes in weathering rates and mechanisms are the barely visible impacts of climate change on cultural heritage. Long-term monitoring of built and archaeological heritage is therefore necessary to ascertain the nature of loss due to slow onset effects. During research at the Dublin Institute of Technology in 2011 a Legacy Indicator Tool (LegIT) for measuring the weathering of stone surfaces into the far future was developed by the author and piloted at five National Monuments in Ireland. While it is too soon to evaluate the tool in relation to long term climate change trends, this article considers the data from 5 years of exposure and provides an early assessment of the pilot study's design and implementation.

Results: Measurements for colour, surface roughness, weight, and dimensions from the 5 year exposure of the LegIT were analysed. Comparisons between sites allows assessment of surface change under different atmospheric conditions. The indications for regional and localized weathering trends will aid managers in understanding risks and setting priorities—both for further monitoring and for conservation interventions.

Conclusions: Results from the 5 year pilot trial of the LegIT has allowed preliminary evaluation of its potential as a long term indicator for surface weathering. Recommendations have been made for modifications to the design, manufacture and implementation of the tool. The future aim is to compare results over time at each site, building a picture of surface weathering processes in relation to regional climatic change.
\end{abstract}

Keywords: Cultural heritage, Archaeology, Management, Climate change, Stone, Weathering, Monitoring, Indicator

\section{Introduction}

The catastrophic impacts of climate change on the historic environment, such as increased flooding and coastal erosion, are increasingly widely recognised. What is less visible but potentially more widespread is the gradual change in preservation conditions and resultant deterioration. Monitoring of outdoor heritage artefacts and structures is necessary to ascertain the rate and scale of loss due to weathering. It may prove difficult to maintain such programmes over the long term however, a problem that is increasingly relevant as patterns of deterioration alter due to the progression of climate change [1-4].

*Correspondence: cdaly@lincoln.ac.uk

School of History and Heritage, University of Lincoln, Brayford Pool, Lincoln LN6 7TS, UK
During research at the Dublin Institute of Technology in 2011 a Legacy Indicator Tool (LegIT) for measuring the weathering of stone surfaces into the far future was developed by the author and piloted at five National Monuments in Ireland. Indicators can be used as proxies for processes not directly observable or involving interactions over a long period (as in the case of climate change). The purpose, design and functionality of the LegIT has been described previously [5]. In brief, the intention was to create an indicator tool that was capable of signposting:

a. The nature (dominant mechanisms, relative severity etc.) of surface weathering at the site, and

b. Whether those effects alter over time with changes in the climate. 

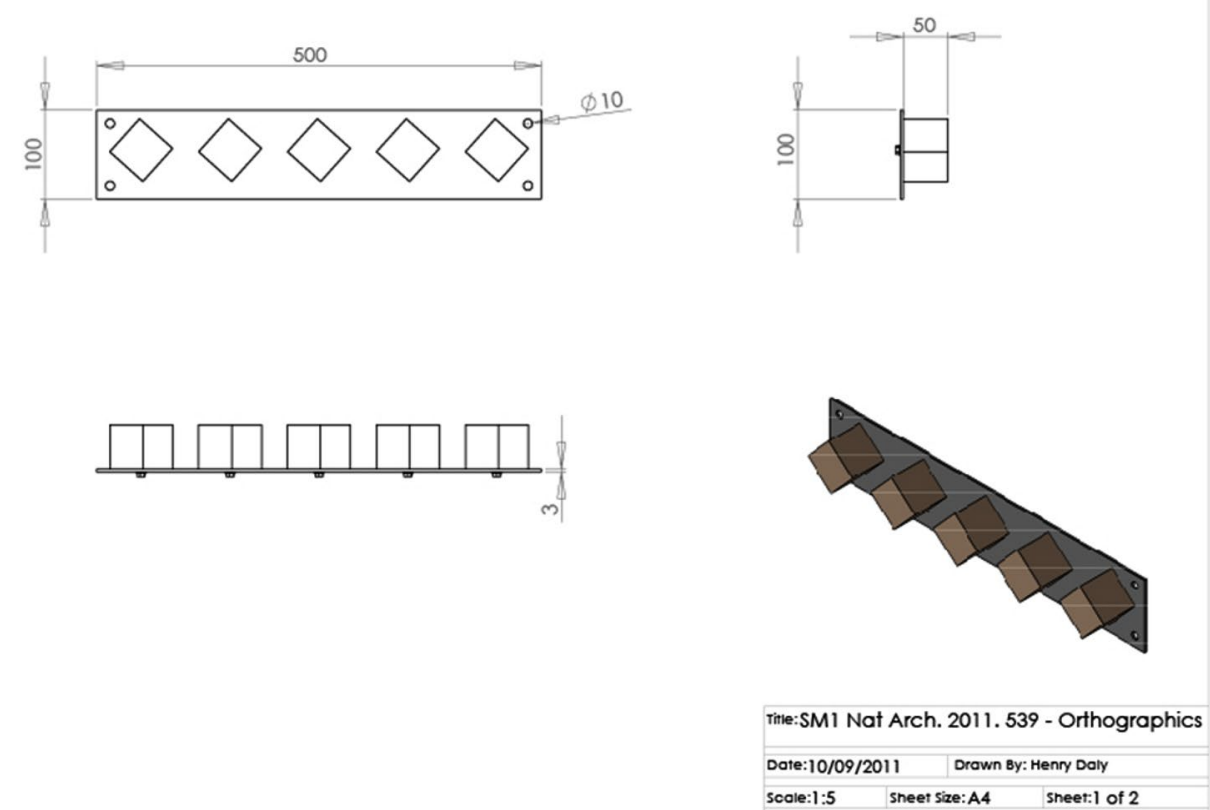

Fig. 1 LegIT design; cubes attached to stainless steel plates with stainless steel (bolt and inset nut) fixing system

It was intended that this information would inform decision making regarding the allocation of resources to monitoring and conservation campaigns. While it is too soon to evaluate the tool in relation to long term climate change trends, this article considers the data from 5 years of exposure and provides an early assessment of the pilot study.

\section{Methods}

Brimblecombe suggests that an embedded tool, capable of gathering and storing data without maintenance or management requirements would be ideal for monitoring climate change impacts on individual heritage sites [2]. The LegIT is an attempt to create one such tool, in this case for the capture of surface and near surface effects such as physical and chemical surface recession and microbiological activity. These are the issues noted by Noah's Ark [6] and others [7, 8] as being of primary concern for heritage in Western Europe under future climate projections.

The LegIT consists of five $50 \mathrm{~mm}^{3}$ cubes attached to a stainless steel plate (Fig. 1). Each of the five cubes is of a different material, four reference materials (Peakmoor sandstone, Portland Limestone, concrete and historic brick) are common to all plates; the fifth is a locally representative stone, and is unique to each site. The LegIT includes materials with a range of sensitivities to climate influences in order to ensure an early indication of weathering patterns. Between 2011 and 2013 three plates were placed at each of the five case-study National Monuments $^{1}$ in Ireland, Brú na Bóinne, Clonmacnoise, Dublin Castle, the Rock of Cashel and Skellig Michael. The choice of location for the LegIT plates was negotiated for each site with the conservation architects. Positioning took into account the visual and physical integrity of the monuments, security of the plates, and the potential for reflecting different micro-climates on site. The cubes were measured prior to exposure of the LegIT with the intention that they be left in place for the long-term, ideally being re-measured every 3-5 years to monitor cumulative surface change. If this regime is interrupted or abandoned assessment can begin again at a far-future date utilising the archived data for comparative purposes. Atmospheric climate data (temperature, precipitation and humidity) is available for the site of Clonmacnoise, data from nearby meteorological stations operated by Met Eireann can be used for the other four sites.

\footnotetext{
${ }^{1}$ Brú na Bóinne and Skellig Michael are also UNESCO designated World Heritage properties.
} 
During the pilot trial some data was lost from vandalism ( 1 cube stolen), accidental damage ( 1 cube broken), and miscommunication (steam cleaning of one plate). There was also a 3 year delay in the installation of the plates at Dublin Castle, resulting in an absence of data from the site. This occurred initially because of staff changes and failures in communication, but its continuation for such a long period (until 2016) was due to the fact that the project had not been integrated within the site management remit.

The different measurement methods adopted during the pilot study to measure changes to the surface of the cubes are outlined in Table 1. Three dimensional profiling was utilised in the initial phase in 2011 but problems in relation to repeat access to equipment, software expertise, and ease of use meant this was not repeated. The stylus profilometer used for taking surface roughness measurements is intended primarily for metals engineering applications and is not ideally suited to porous surfaces [9]. In some cases the stone samples became sufficiently rough after exposure as to lie outside the cut-off point of the device i.e. they were too rough for the machine to measure. The potential of Reflectance Transformation Imaging (RTI) as a substitute method for relative surface roughness measurement was explored but experiments indicated that colour change due to algal growth would interfere with the measurements, thereby disallowing quantitative comparisons over time [10]. Various techniques for assessing surface roughness of weathered stone have been described in the literature including laser scanning, micro-roughness meters and visual/tactile evaluations [11-14]. In all cases there are limitations in either accuracy or the potential for long-term sustainability of the methods outlined [12]. Resolving this issue will be one focus of the next phase of the project.

Table 1 Measurement methods utilised for LegIT

\begin{tabular}{|c|c|c|c|}
\hline Method and requirements & Procedure & Resource implications & Comment \\
\hline $\begin{array}{l}\text { Photography } \\
\text { Digital camera, tripod }\end{array}$ & $\begin{array}{l}\text { Digital colour photographs, of } \\
\text { each exposed face. Change } \\
\text { visually quantified using grid } \\
\text { overlay }\end{array}$ & $\begin{array}{l}\text { Financial: low_-basic equipment. } \\
\text { Human: low-medium_taking, } \\
\text { assessing and archiving digital } \\
\text { images. No expertise required }\end{array}$ & $\begin{array}{l}\text { Low tech, comparison will be visual } \\
\text { and somewhat subjective }\end{array}$ \\
\hline $\begin{array}{l}\text { Average surface roughness (Ra) } \\
\text { surface characterization tool e.g. } \\
\text { Diavite or Surtronic. Industry } \\
\text { standard settings used = Lt } \\
4.80 \mathrm{~mm} \text { trace (sample length) } \\
\text { and Lc } 0.8 \text { cut off filter (does not } \\
\text { measure wavelengths }>0.8 \mathrm{~mm} \text { ) }\end{array}$ & $\begin{array}{l}\text { The profile of the surface is meas- } \\
\text { ured using a stylus, magnified } \\
\text { through software and quanti- } \\
\text { fied as roughness average }(\mathrm{Ra}) \\
\text { in } \mu \mathrm{m} \text {, accurate to } 0.01 \mathrm{~mm} \\
\text { Average taken from } 10 \text { profiles on } \\
\text { each exposed face }\end{array}$ & $\begin{array}{l}\text { Financial: medium_equipment cost } \\
\text { approx. } € 3000 \\
\text { Human: medium_taking } 50 \text { meas- } \\
\text { urements/cube is time consuming } \\
\text { however very little post-measure- } \\
\text { ment processing is required, no } \\
\text { expertise required }\end{array}$ & $\begin{array}{l}\text { Highlights changes in surface } \\
\text { characteristics, e.g. smoothing or } \\
\text { roughening } \\
\text { Standard deviation in the Ra measure- } \\
\text { ments can be used to indicate } \\
\text { homogeneity of the surface } \\
\text { Cannot be used on very weathered } \\
\text { stone or over large lichen growths }\end{array}$ \\
\hline $\begin{array}{l}\text { Colour meter/spectrophotometer } \\
\text { Ultra Scan Pro USP1577 Hunter Lab. } \\
\text { Mode \#3 RSEX or similar }\end{array}$ & $\begin{array}{l}\text { Values for brightness }\left(\mathrm{L}^{*}\right) \text { redness } \\
(\mathrm{a}+) \text { and yellowness }(\mathrm{b}+) \text { are } \\
\text { taken. Average values are calcu- } \\
\text { lated from the five points by the } \\
\text { spectrometer }\end{array}$ & $\begin{array}{l}\text { Financial: medium-low_from } € 3000 \\
\text { to buy, the project initially used } \\
\text { borrowed equipment at a food } \\
\text { science lab. } \\
\text { Human: low-spot readings can be } \\
\text { taken rapidly and processed imme- } \\
\text { diately by software, no expertise } \\
\text { required }\end{array}$ & $\begin{array}{l}\text { Colorimetry has successfully been } \\
\text { used as a measure of biomass on } \\
\text { stone [ [15], [16] ]. Visual examination } \\
\text { must accompany this assessment }\end{array}$ \\
\hline $\begin{array}{l}\text { Callipers } \\
\text { Vernier callipers }\end{array}$ & $\begin{array}{l}\text { Digital Vernier callipers. Measure- } \\
\text { ments taken in three dimen- } \\
\text { sions (width, depth and height). } \\
\text { Three measurements taken in } \\
\text { each case. }\end{array}$ & $\begin{array}{l}\text { Negligible-low cost equipment, } \\
\text { low human resources_rapidly } \\
\text { completed by non-expert }\end{array}$ & $\begin{array}{l}\text { Produces quantifiable measurements } \\
\text { but of low accuracy ( } \pm 0.1 \mathrm{~mm} \text { ) } \\
\text { Margin for human error (estab- } \\
\text { lished from repeat measurements) } \\
\text { is } \pm 0.3 \mathrm{~mm}\end{array}$ \\
\hline $\begin{array}{l}\text { Weight } \\
\text { Digital laboratory scales (measure } \\
\text { to } 0.00 \mathrm{~g} \text { ). }\end{array}$ & $\begin{array}{l}\text { Demounted stones (including } \\
\text { internally fixed nut) weighed } \\
\text { in grams. Stones must be dry } \\
\text { before weighing. Calibrate } \\
\text { scales }\end{array}$ & $\begin{array}{l}\text { Financial: low_scales from } € 250 \\
\text { to buy } \\
\text { Human: low_quick to take meas- } \\
\text { urements, no expertise required }\end{array}$ & $\begin{array}{l}\text { The requirement for drying the stones } \\
\text { can delay this method of assessment } \\
\text { for several weeks after demounting }\end{array}$ \\
\hline $\begin{array}{l}\text { 3D profile scanning } \\
\text { Renishaw Cyclone Series } 2 \text { SP600 M } \\
\text { machine or similar. Used Tracecut } \\
\text { programme } \\
\text { NB this method was utilized in the } \\
\text { initial phase but not for repeat } \\
\text { measurements }\end{array}$ & $\begin{array}{l}\text { Profiling done in Z plane in incre- } \\
\text { ments of 5-10 mm (i.e. profiles } \\
\text { taken at 45,40,35, 30, } 20 \text { and } \\
10 \mathrm{~mm} \text { from base). Profiles } \\
\text { stored as DXF lines and arcs } \\
\text { in CAD }\end{array}$ & $\begin{array}{l}\text { Financial: high_cost of equipment } \\
\text { prohibitive unless can access } \\
\text { within an institution } \\
\text { Human: high-time consuming to } \\
\text { take measurements and to process } \\
\text { and requires expertise }\end{array}$ & $\begin{array}{l}\text { The measurements could be } \\
\text { introduced into CAD software to } \\
\text { compare profiles over time, quantify } \\
\text { change and produce visual overlays } \\
\text { that show the progression of loss }\end{array}$ \\
\hline
\end{tabular}




\section{Results}

The data from the pilot exposure of the LegIT has been analysed for both the nature and scale of measured change and a selection of the results are considered here to illustrate trends. Prior to undertaking paired $\mathrm{T}$ tests the data was checked for normality and outliers using statistical analysis software (SPSS) (histograms, QQ plots and Box plots). Significant outliers (at $1 \mathrm{QR} \geq 3$ ) were identified and removed. While comparisons between sites allows assessment of surface change under different atmospheric conditions, the future aim is to compare results over time at each site, building a picture of surface weathering processes in relation to regional climatic change.

\section{Colour}

Colorimetry has successfully been used as a measure of biomass on stone $[15,16]$. For the LegIT, colour change was measured with a spectrometer using the $\mathrm{L}^{*} \mathrm{a}$ "b* colour space system where $L^{*}$ represents lightness and $a^{*}$ and $b^{*}$ represent hue. The red/green spectrum is represented by $a^{*}$ values, while the yellow/blue spectrum is represented by $b^{*}$ values; $+a^{*}$ is the red direction; $-a^{*}$ is the green direction; $+b^{*}$ is the yellow direction and $-b^{*}$ is the blue direction (Table 2) [17]. Five spot readings were taken and averaged for each exposed face $(25$ readings/cube).

Reduction in lightness occurred on cubes from all four sites, indicated by a negative $\Delta \mathrm{L}^{*}$, the largest (43\%) reduction was recorded on the local sandstone in Clonmacnoise. All of the Peakmoor and Portland cubes showed a similar degree of darkening. Peakmoor also showed the greatest degree of greening across all sites. Sandstone is known to be particularly susceptible to biological colonization [18] which is the likely explanation for these results. Table 3 shows the $\Delta \mathrm{L}, * \Delta \mathrm{a}^{*}$ and $\Delta \mathrm{b}^{*}$ values for Peakmoor cubes across the 4 case study sites.

The impact of aspect and micro-climatic conditions on biological growth is evidenced in the differences in colour between cubes in different locations on the same site. For example, on Skellig Michael plates 2 and 3 (both in exposed locations) the colour change follows a similar pattern of darkening, greening and blueing (Table 3 ). Plate 1 however, which is in a more sheltered position at the upper lighthouse, shows a different pattern with a large increase in yellowing. A similar pattern can be seen with the Rock of Cashel plates, plate 2 (in a sheltered position on the cross walk of the cathedral) showing higher values for darkening $\left(-\mathrm{L}^{*}\right)$, greening $\left(-\mathrm{a}^{*}\right)$ and particularly for yellowing $\left(+b^{*}\right)$. Cross-referencing the L"a*b* data with digital images of the cubes (see Fig. 2) confirms this, as there is also an obvious visual difference in the micro-biological growth occurring at the two different locations on the Rock of Cashel.

\section{Visual analysis}

While colour measurements provide information on the presence of biofilms, these needed to be considered in conjunction with visual data when interpreting the results. For example, visual examination showed that lichens had rapidly colonized the cubes in Clonmacnoise growing large thalli (fungal bodies), a very different pattern of growth to the other sites and not one that could be communicated through colour data alone (Fig. 3).

The growth rate of lichens will vary according to species, crustose lichens tend to be slow growing $(0.1 \mathrm{~mm}-2 \mathrm{~mm} /$ year$)$ while foliose lichens will grow between 0.5 and $4 \mathrm{~mm} /$ year [19]. For all species growth rate is dependent on the environment, ideal conditions being high moisture availability and mild temperatures.

Table 2 L*a*b* colour system

\footnotetext{
$\Delta L^{*}=\left(L^{*}\right.$ pre-exposure $-L^{*}$ post exposure $)=$ difference in lightness $(+=$ lighter $/-=$ darker $)$

$\Delta \mathrm{a}^{*}=$ ( $\mathrm{a}^{*}$ pre-exposure $-\mathrm{a}^{*}$ post exposure $)=$ difference in red and green $(-=$ greener $)$

$\Delta \mathrm{b}^{*}=\left(\mathrm{b}^{*}\right.$ pre-exposure $-\mathrm{b}^{*}$ post exposure $)=$ difference in yellow and blue $(+=$ yellower $)$
}

Table $3 \Delta L^{*} \Delta a^{*}$ and $\Delta b^{*}$ values for Peakmoor cubes from 4 case study sites for exposures of 3-5 years

\begin{tabular}{|c|c|c|c|c|c|c|c|c|c|c|c|c|}
\hline \multirow[t]{2}{*}{ Plate } & \multicolumn{3}{|c|}{$\begin{array}{l}\text { Skellig Michael } \\
2011-2016\end{array}$} & \multicolumn{3}{|c|}{$\begin{array}{l}\text { Bru na Boinne } \\
\text { 2012-2016 }\end{array}$} & \multicolumn{3}{|c|}{$\begin{array}{l}\text { Rock of Cashel } \\
2013-2016\end{array}$} & \multicolumn{3}{|c|}{$\begin{array}{l}\text { Clonmacnoise } \\
\text { 2013-2016 }\end{array}$} \\
\hline & $\Delta \mathrm{L}^{*}$ & $\Delta \mathrm{a}^{*}$ & $\Delta \mathbf{b}^{*}$ & $\Delta \mathrm{L}^{*}$ & $\Delta \mathrm{a}^{*}$ & $\Delta \mathrm{b}^{*}$ & $\Delta \mathrm{L}^{*}$ & $\Delta \mathrm{a}^{*}$ & $\Delta \mathrm{b}^{*}$ & $\Delta \mathrm{L}^{*}$ & $\Delta \mathrm{a}^{*}$ & $\Delta \mathbf{b}^{*}$ \\
\hline 1 & -14.8 & -0.5 & +4.1 & -17.1 & -2.3 & +7.8 & -14.68 & -1.33 & +0.53 & -20.41 & -3.33 & +4.62 \\
\hline 2 & -13.5 & -1.8 & -1.8 & -10.7 & -2.1 & +10.4 & -18.01 & -4.02 & +7.65 & -17.1 & -1.46 & +1.62 \\
\hline 3 & --12.5 & -1.3 & -1.92 & -12.4 & -2 & +12.6 & & & & -20.41 & -2.2 & +0.01 \\
\hline
\end{tabular}




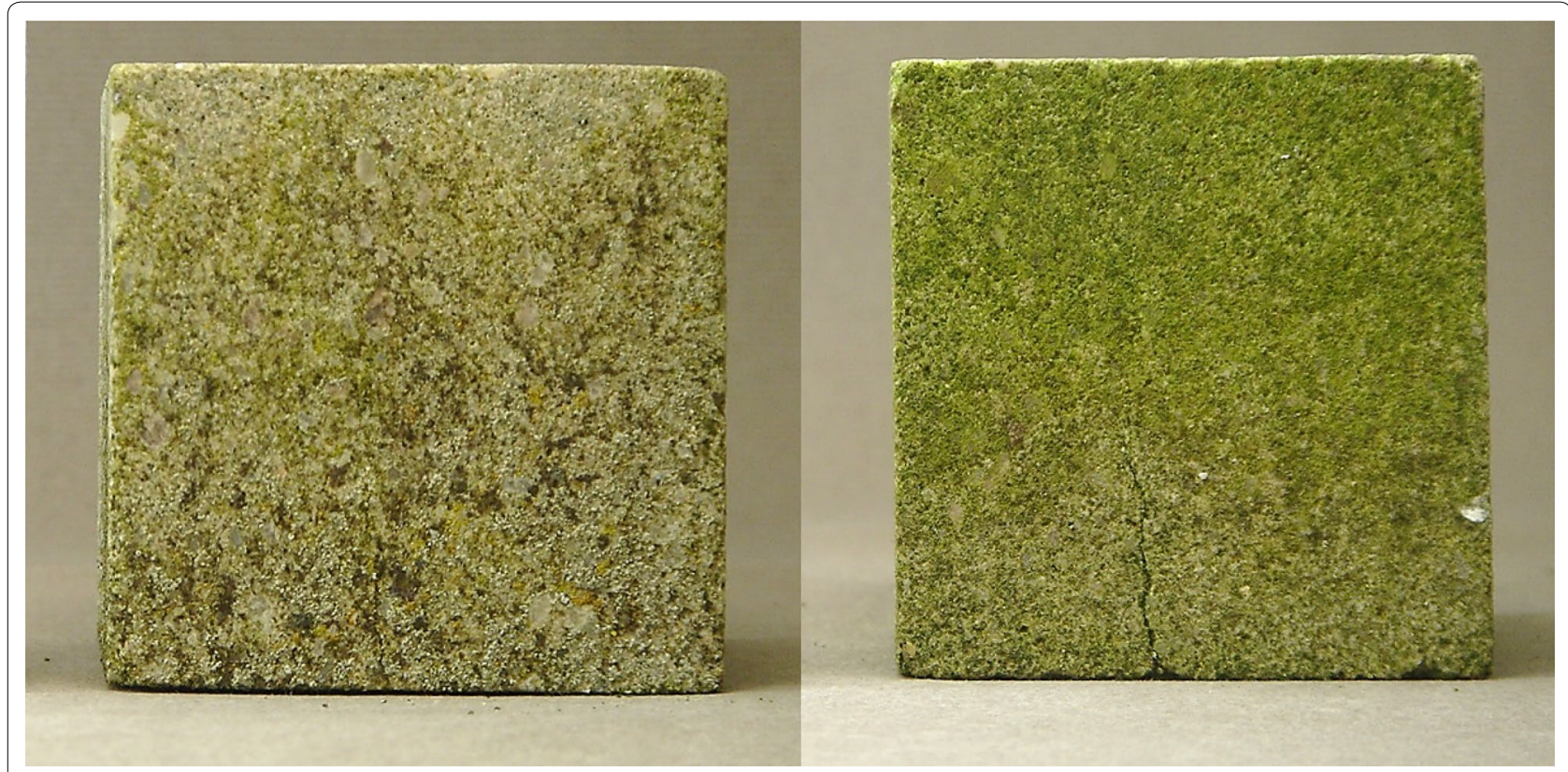

Fig. 2 Micro-climatic effects on biofilm growth: Rock of Cashel Peakmoor cubes 2016, plate one (left) and plate two (right)

With this in mind the number of rain days $(\geq 2 \mathrm{~mm})$ for two of the exposure years (2014 and 2015) were compared across the LegIT sites (Fig. 4). ${ }^{2}$ Unfortunately neither of the World Heritage properties has on site recording of environmental climate therefore data has to be used from the closest available met stations. These are Valentia Observatory, Cahersiveen Co. Kerry, which is approx. $30 \mathrm{~km} \mathrm{NW}$ of Skellig Michael, and Dunsany automatic weather station in Co Meath which is approx. $20 \mathrm{~km} \mathrm{SW}$ of Brú na Bóinne [20]. Precipitation data, without wind measurement, is available for the site of Clonmacnoise and for Ballinamona $(3.5 \mathrm{~km} \mathrm{~W}$ of the rock of Cashel). During this period Clonmacnoise experienced 43-49 more wet days than Cashel or Brú na Bóinne, but 38 days less than Skellig. Temperature readings are not available from the stations at Cashel for this period but non-quality controlled readings were sourced for Clonmacnoise. ${ }^{3}$ The indication from this data is that Clonmacnoise may not only be wetter than the other rural sites, but also experiences milder temperatures. Regional variation in lichen growth cannot be explained solely in relation to mild temperatures and the availability of water however, otherwise Skellig Michael would have the highest growth rate.

\footnotetext{
${ }^{2}$ Values from Met Eireann (Irish meteorological services) online database of climate data at http://www.met.ie/climate-request/ (accessed 1/10/18). Clonmacnoise temperature data provided by Aidan Murphy, Climate Services, Met Eireann (15/10/18).

${ }^{3}$ Obtained by Email from Aidan Murphy, Climate Services, Met Éireann, 15.10.2018.
}

A non-climatic influencing factor on biological growth on stone is air quality and although most lichens will not grow in a polluted environment, the presence of elevated levels of atmospheric nitrogen may act as a biofilm fertilizer [21]. All of the case study sites are in Zone D of Ireland's Environmental Protection Agency's (EPA) air quality management plan (rural areas and towns $<15,000$ population). While this suggests there should be little difference in the air quality between the sites, in reality this may not be the case-both Brú na Bóinne and Clonmacnoise are located in regions with fuel burning power stations (West Offaly peat burning station is approximately $8 \mathrm{~km} \mathrm{SW}$ of Clonmacnoise and the Indaver waste to energy incinerator is approximately $6 \mathrm{~km} \mathrm{SE}$ from Newgrange $^{4}$ ) while the Rock of Cashel is within a town environ. In the case of Skellig Michael the exposed maritime environment, with high winds and air borne salts is also likely to be influencing biofilm growth.

\section{Surface roughness}

Change in average surface roughness ( $\mathrm{Ra}$ ) of the cubes was examined in relation to both material type and site location. It is should be noted that the utilisation of the surface profilometer to measure $\mathrm{Ra}$ of the artificial cubes (concrete and brick) was unsuccessful due to the heterogeneity of these aggregated materials, therefore this analysis

\footnotetext{
${ }^{4}$ The prevailing wind direction is from the South and West, likely to carry pollution from Shannonbridge over Clonmacnoise but should have the reverse effect with the exhaust from Indaver, as it lies to the SE of Brú na Bóinne.
} 

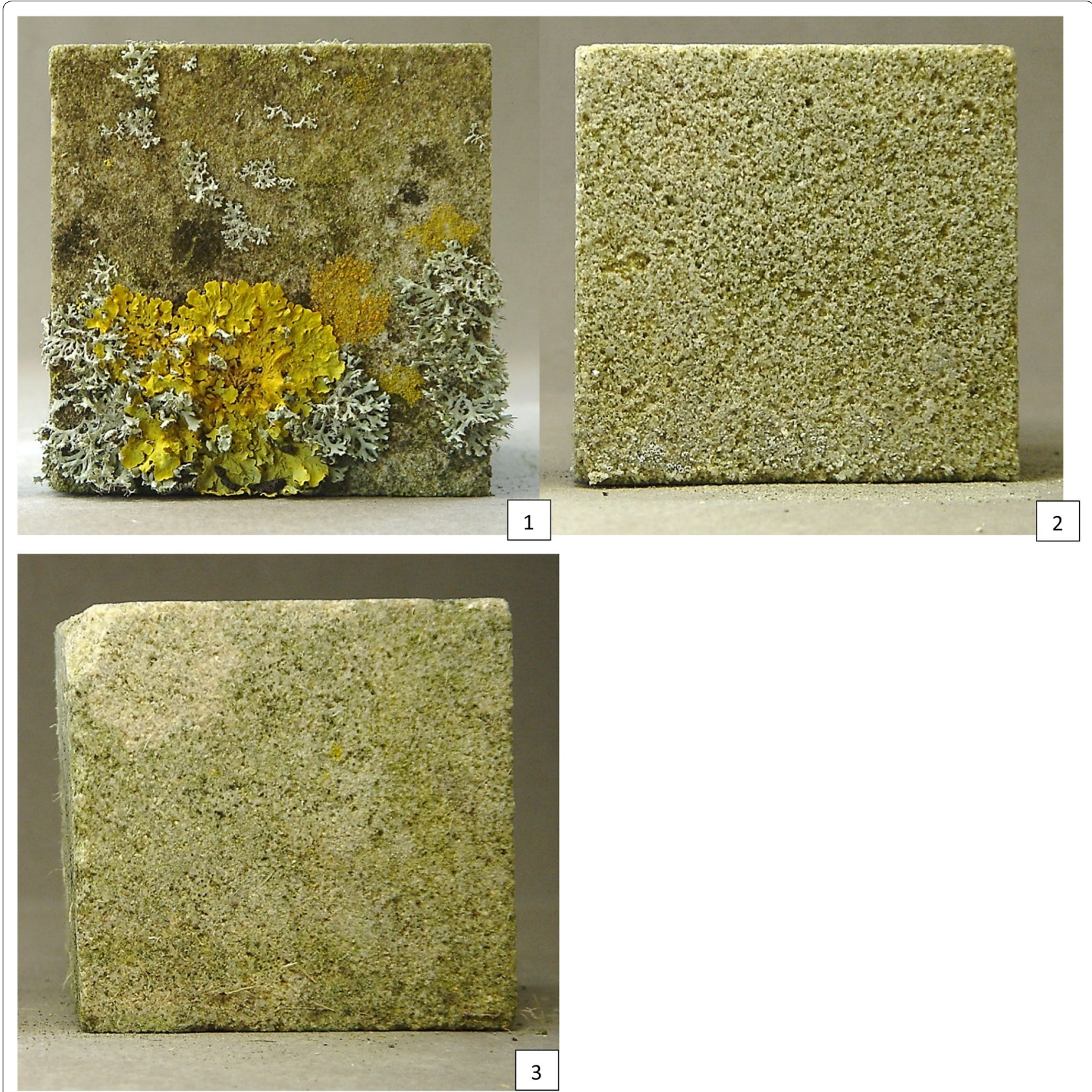

Fig. 3 Visual appearance of biofilms on Peakmoor cubes across 3 sites (for Rock of Cashel see Fig. 2). 1. Clonmacnoise Peakmoor 22016 after 3 years exposure (side). 2. Skellig Michael Peakmoor 22016 after 5 years exposure (side). 3. Brú na Bóinne Peakmore 22016 after 5 years exposure (side)

concentrates on the natural stone cubes. In some cases lichen growth had to be removed before measurement could be taken (this was done with the pad of a finger to minimise scratching to the surface). While this action was undertaken after photography and colour measurement, it does remove the ability to monitor cumulative patterns in biological growth. In addition as the lichens form a protective layer over the stone but are attached to the surface with hyphae strands, removal (however gently) may loosen and remove grains from the stone-artificially increasing the roughness. That biological growth may prevent surface roughness measurement (and vice versa) is significant for future implementation, essentially requiring the researcher to prioritise a specific data-set.

Examination of the data for Portland Limestone (Fig. 5) and Peakmoor sandstone cubes revealed several patterns. 


\section{Number of rain days $(0.2 \mathrm{~mm}$ or more) and number of cold days $\left(\angle 0^{\circ} \mathrm{C}\right)$ in the period 01/01/2014-31/12/2015}

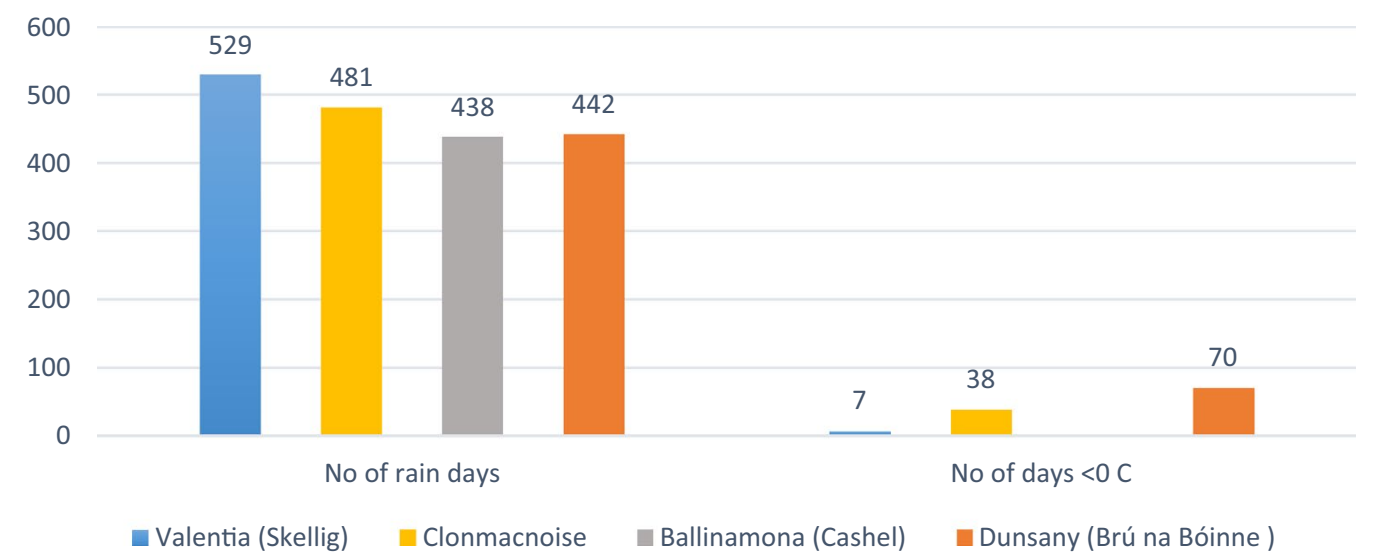

Fig. 4 Comparison of number of rain days and cold days between 4 sites for a 24 month period (2014-2016)

Firstly, roughness is a factor of time, i.e. those sites with 3 years exposure do not show as much change as those where the cubes have been exposed longer. While this illustrates that roughening is exponential initially, the long-term pattern may prove to be less linear. Assuming that the softer parts of the surface will be eroded first, this should initially cause an increase in roughness. The grains/nodules of harder materials exposed as a result are then likely to be eroded, essentially levelling the surface somewhat as the stone recedes, potentially reducing roughness [11]. To date the cubes have continued to increase in roughness, however, if it does reduce subsequently and then increase again, this could in itself be utilised to establish a pattern of weathering.

A second notable pattern is that there is a variation between the same stone types in different locations-the dependant variable therefore being local climate conditions. For example, Skellig Michael clearly shows much greater surface roughening than Brú na Bóinne, although the cubes on both sites have been exposed for the same period of time (Fig. 6). Surface roughness may be caused by the physical action of salt crystallisation, however the visual characteristics of salt weathering (powdering stone, spalling surface, salt crystals) was not evidenced on any of the samples and the most likely cause of measured change was determined to be surface erosion by rain [22], with additional contributing factors being wind and solar radiation.

Comparing the data for annual rainfall volume for the exposure period illustrates a significant difference between the three regions (Kerry receiving almost double the volume of Meath) (Fig. 7). This may indicate that the increase in surface roughening is due to physical erosion of the surface by rain, the fact that wind speeds are also consistently higher in Kerry than Meath implies that the effect of wind driven rain may also be a factor. It must be noted that the mechanisms of stone decay are complex and establishing causality for certain will require monitoring of a range of environmental parameters. Aspect is also likely to be a contributing factor, with more erosion expected where the LegIT is exposed to prevailing winds and solar radiation, however this is not yet distinguishable within the short term data. Nonetheless, the results for $\mathrm{Ra}$ to date do clearly illustrate that location (and therefore climatic differences) influences recession.

\section{Weight and dimensional change}

Measuring the dimension and weight of each cube over time is a quick and low-cost method for quantifying change. Weight change has been used previously to monitor the weathering and recession of exposed limestone samples across Europe [12, 23]. The LegIT measurements were taken after the cubes had air dried and large lichen growths had been removed. The removal of lichens was necessary for surface roughness measurement and it was decided to measure weight after this was undertaken, and to repeat the same procedure in future. When comparing pre and post exposure weights of LegIT samples, in most cubes the differences were due to weight gain rather than loss (Fig. 8). It should be noted that in most cases the weight gain seen was $1 \mathrm{~g}$ or below, and as the average weight of the cubes is around $280 \mathrm{~g}$ this represents 


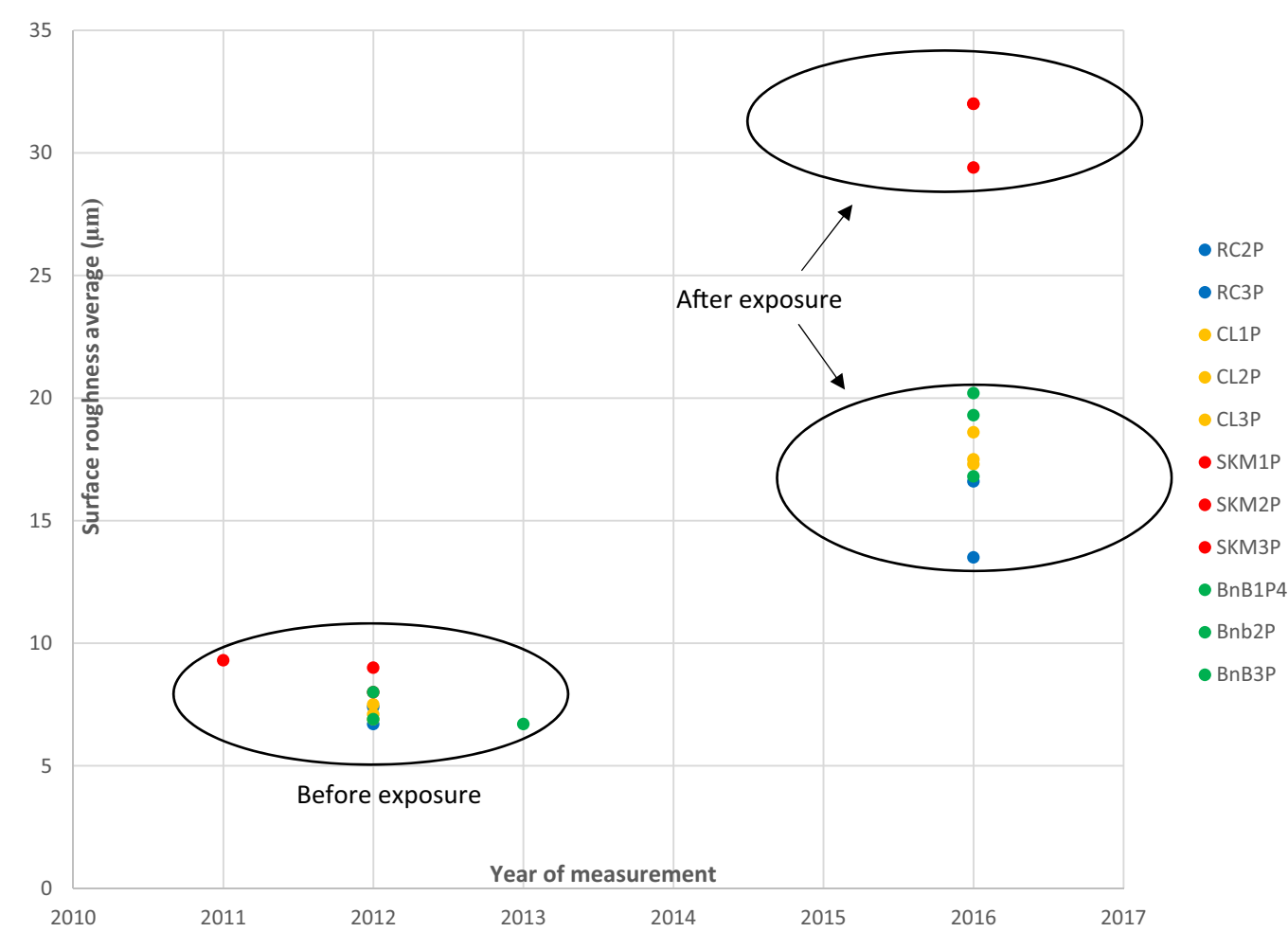

Fig. 5 Comparison of Surface roughness measurements for 3 plates (1-3) for Portland limestone (P) across 4 heritage sites (RC: Rock of Cashel; CL: Clonmacnoise; SKM: Skellig Michael; BnB: Brú na Bóinne) before and after exposure

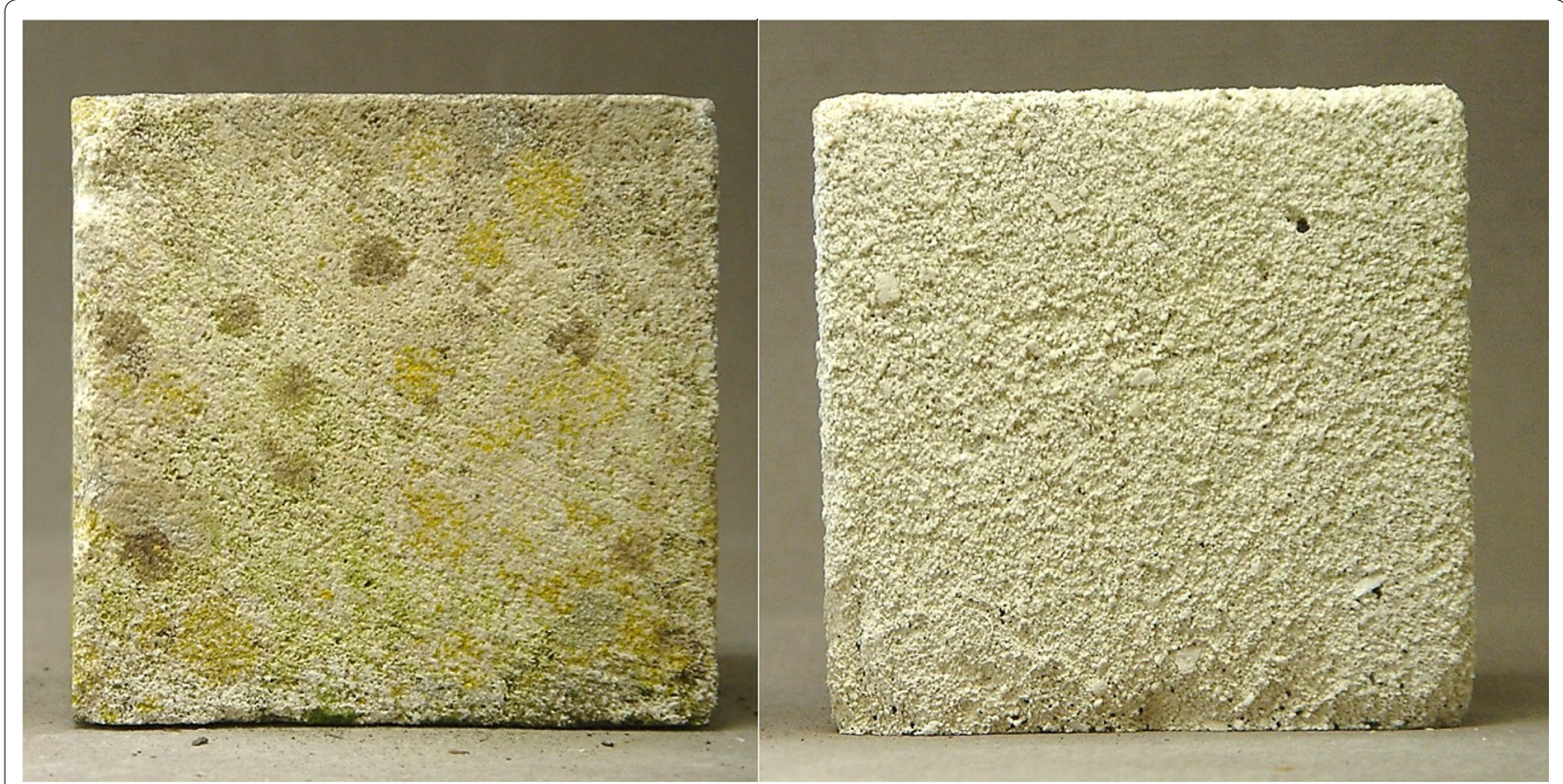

Fig. 6 Visible difference in surface roughness between Portland cubes from Brú na Bóinne 2 (left) and Skellig Michael 3 (right). Photo taken in 2016 


\section{Comparison of annual mean wind speed (Valentia/Dunsany) and total annual} rainfall (Clonmacnoise, Ballinamona, Valentia and Dunsany)
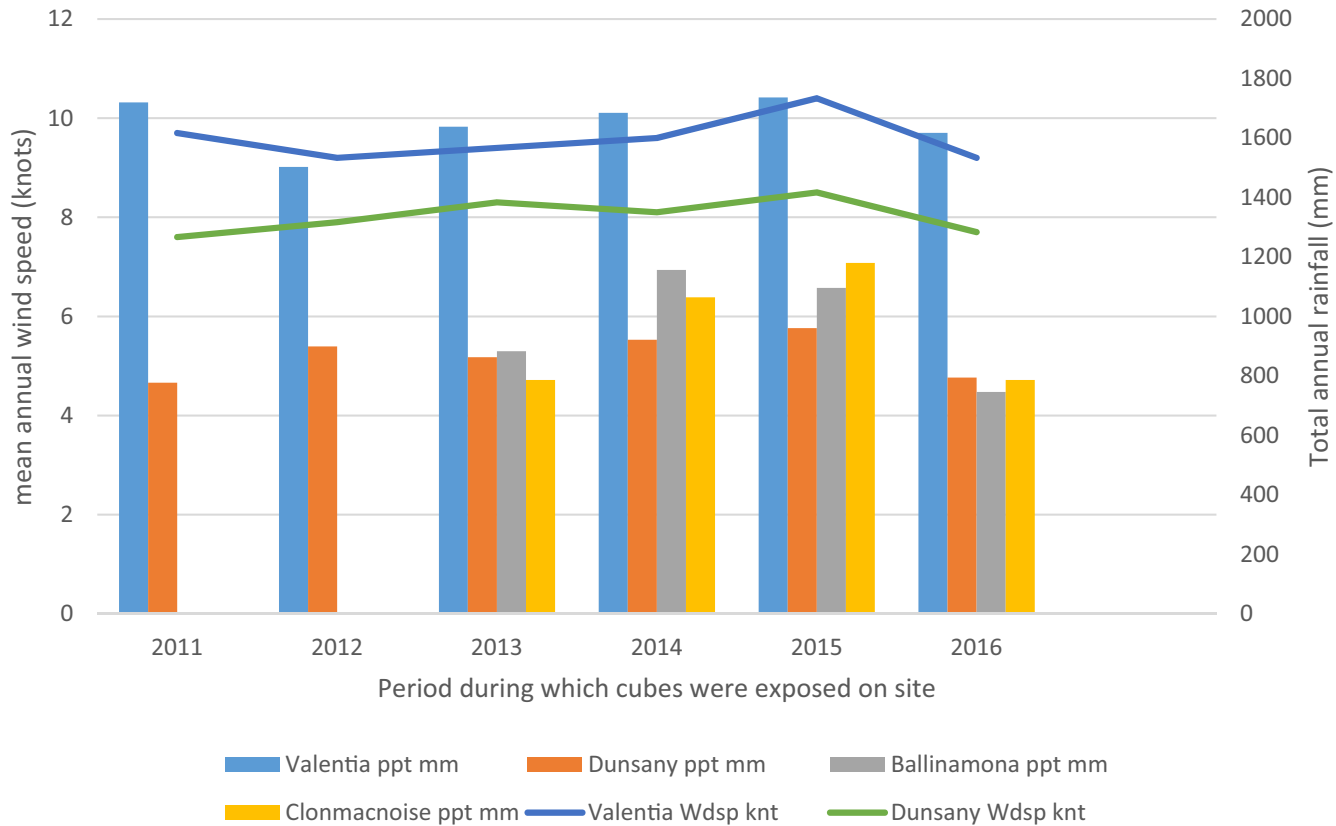

Fig. 7 Wind and precipitation data (Values from Met Eireann (Irish meteorological services) online database of climate data at http://www.met.ie/ climate-request/ (accessed 1/12/17)) from met stations closest to Skellig Michael (Valentia), Brú na Bóinne (Dunsany), Clonmacnoise and Rock of Cashel (Ballinamona)

a small change $<0.5 \%$. Notable weight loss was only recorded for brick cubes from Clonmacnoise, and for Peakmore cubes from Skellig Michael. There does not appear to be a correlation between this weight loss and a reduction in dimension either e.g. for Peakmoor cubes on Skellig Michael reduction of dimension is within the margin for error for the Vernier Callipers, and the brick cubes on Clonmacnoise in fact show a substantial increase in dimensions (possibly as a result of expanding cracks).

\section{Rock of Cashel and Skellig Michael}

Dimensional measurements were taken with Vernier callipers, an extremely accurate manual measuring tool. The problem in using them for comparative measurements over time is that the positioning of the calliper jaws may be responsible for some, if not all, of the differences noted. In 53 of the 54 comparative measurements taken after 1 year exposure (Brú na Bóinne and Skellig Michael plate 3), the magnitude of change did not exceed $0.3 \mathrm{~mm}$ (and in most cases was considerably less). From these results a margin of error of $\pm 0.3 \mathrm{~mm}$ was allowed for repeatability, to which an additional margin of human error for reading the callipers $( \pm 0.1 \mathrm{~mm})$ was added.
To date, the difference between pre and post exposure dimensions for cubes from Brú na Bóinne, Clonmacmoise and Rock of Cashel mostly falls within this $( \pm 0.4 \mathrm{~mm})$ margin of error. Skellig Michael measurements demonstrate a much greater degree of alteration over time however, suggesting there is a link between the more extreme climate and the measured changes (see Fig. 9a, b).

\section{Discussion and future development Measured change}

Given projections for a shift towards shorter periods of heavy precipitation at the case study sites, it is expected that the recession rate caused by the physical action of rain will increase over the long term. The initial results from the LegIT show that roughening is being evidenced first on the softer and less dense stones (Peakmoor and Portland) and at the sites where rainfall volume is highest (Skellig Michael), suggesting that the tool will provide a good indication of this impact. The anticipated reduction in mass due to material loss has not manifested in the weight change results. Most cubes actually demonstrating a small gain in weight, possibly due to microbiological colonisation or accumulation of air/water borne pollutants such as soluble salts [23]. While the dimensional 


\section{Difference between pre and post exposure weight (g) Cubes from Brú na Bóinne, Clonmacnoise, Rock of Cashel and Skellig Michael}

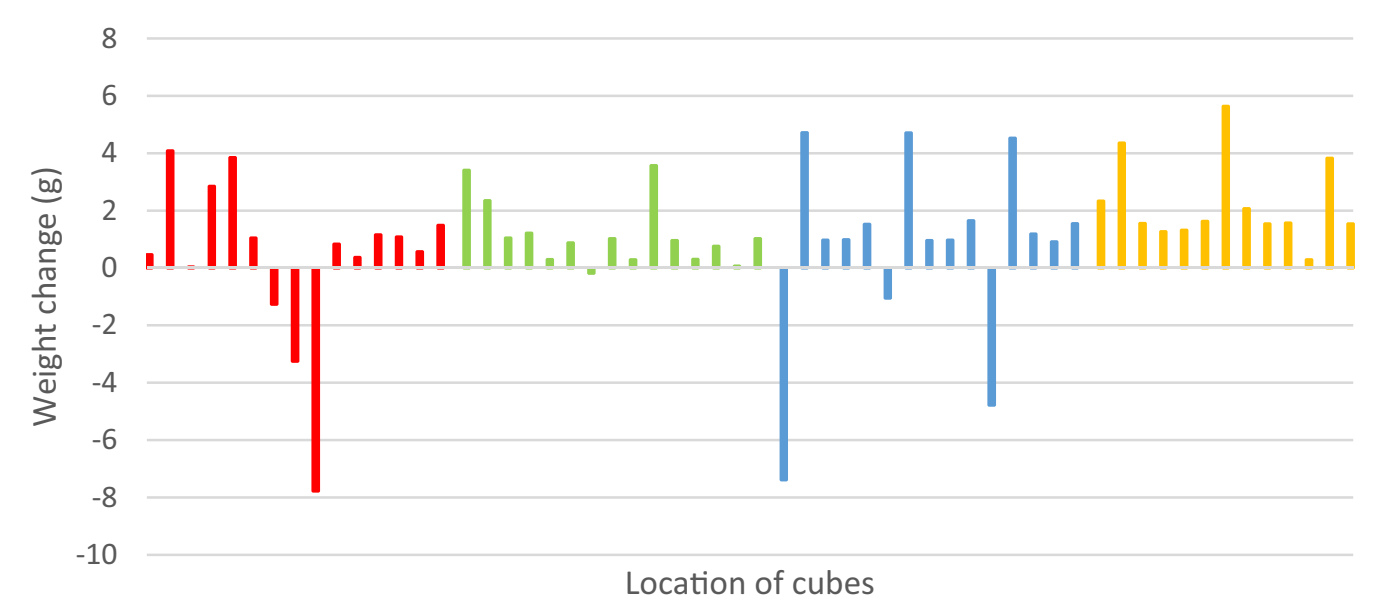

SKM Diff 2011/2016 BnB Diff 2011/2016 Clonmac Diff 2013/2016 RoC Diff 2013/2016

Fig. 8 Weight change due to exposure for cubes from Brú na Bóinne, Clonmacnoise, Rock of Cashel and Skellig Michael

change recorded with Vernier callipers also does not follow a linear pattern of loss-in some instances being due to an increase rather than reduction in dimensionsthere appears to be a relationship in this data between degree of change and length of exposure. In relation to colour change as an indicator of biofilms, there is a notable difference in biological growth type and extent between the locations, due to variations in both regional and local (micro-climatic) environmental conditions.

Surface roughness measurements have proven very useful to date, but as the stones become more weathered they are starting to exceed the sensitivity of the stylus profilimeter. Alternative methods of undertaking surface roughness measurement were investigated and could be trialled during the next phase of the LegIT pilot. The growth of lichens also interfered with these measurements, requiring a choice to be made between the long term measurement of biological growth and of surface roughness.

\section{Design and implementation}

The LegIT was designed to be left to gather data without intervention over the long-term, with potential widespread application for unmanned heritage sites. Accidental and malicious interference has occurred in several instances however resulting in some data loss. In Brú na Bóinne one cube was stolen and others were loosened in situ, in the Rock of Cashel steam cleaning of one plate occurred, while the lacuna in the Dublin Castle data was the result of communication and organisational breakdown (a major challenge for projects that aim to operate over the long-term). Following the discovery of the steam cleaning at Rock of Cashel the plates were moved to an area accessible only to site staff and not external contractors.

The overall design and mounting system worked well during the pilot trial and was found to be practical for installation and demounting. Unfortunately the use of a hammer-drill to create the fixing holes proved problematic as stress cracks have subsequently appeared on some cubes. The inclusion of concrete and brick was intended to widen the application of the LegIT but these materials have proven hard to interpret, partly due to their heterogeneous nature (e.g. aggregate inclusions, air pockets). The act of cutting brick into cubes removed the fired face and therefore rendered it less representative of built fabric. The concrete also required a mould to make the cubes and was particularly difficult to drill.

\section{Future improvements}

The LegIT design is essentially modular, with 5 cubes on each plate, and can therefore be adapted to suit the requirements of any location. Similarly the measurement techniques can be tailored to specific conservation priorities, for example retaining biofilm growth where this is of more interest than surface roughness measurement, 
a Skellig Michael Vernier Calipers measurements difference due to exposure after 1 year (2012) and 5 years (2016)

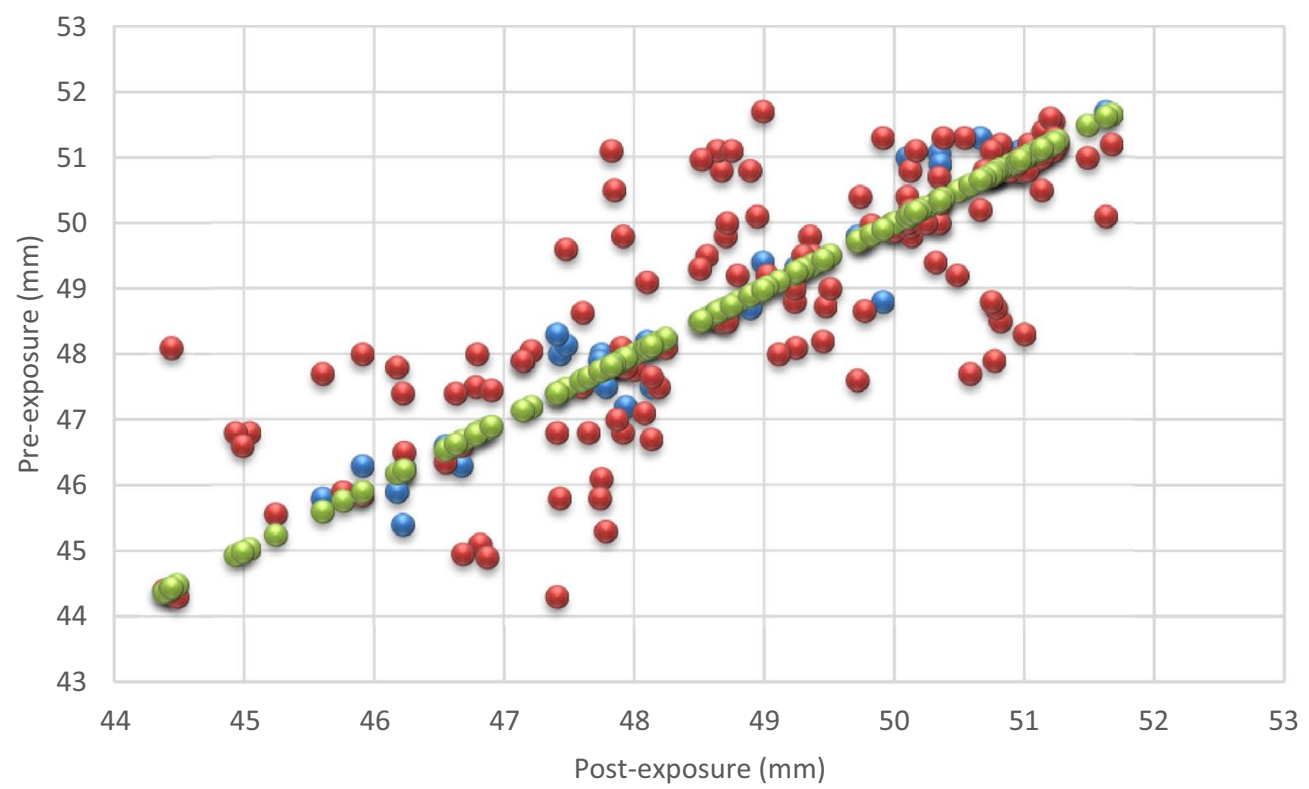

2012 - 2016 Pre-exposure (2011)

b

Brú na Bóinne Vernier Calipers measurements difference due to exposure after 1 year (2013) and 4 years (2016)

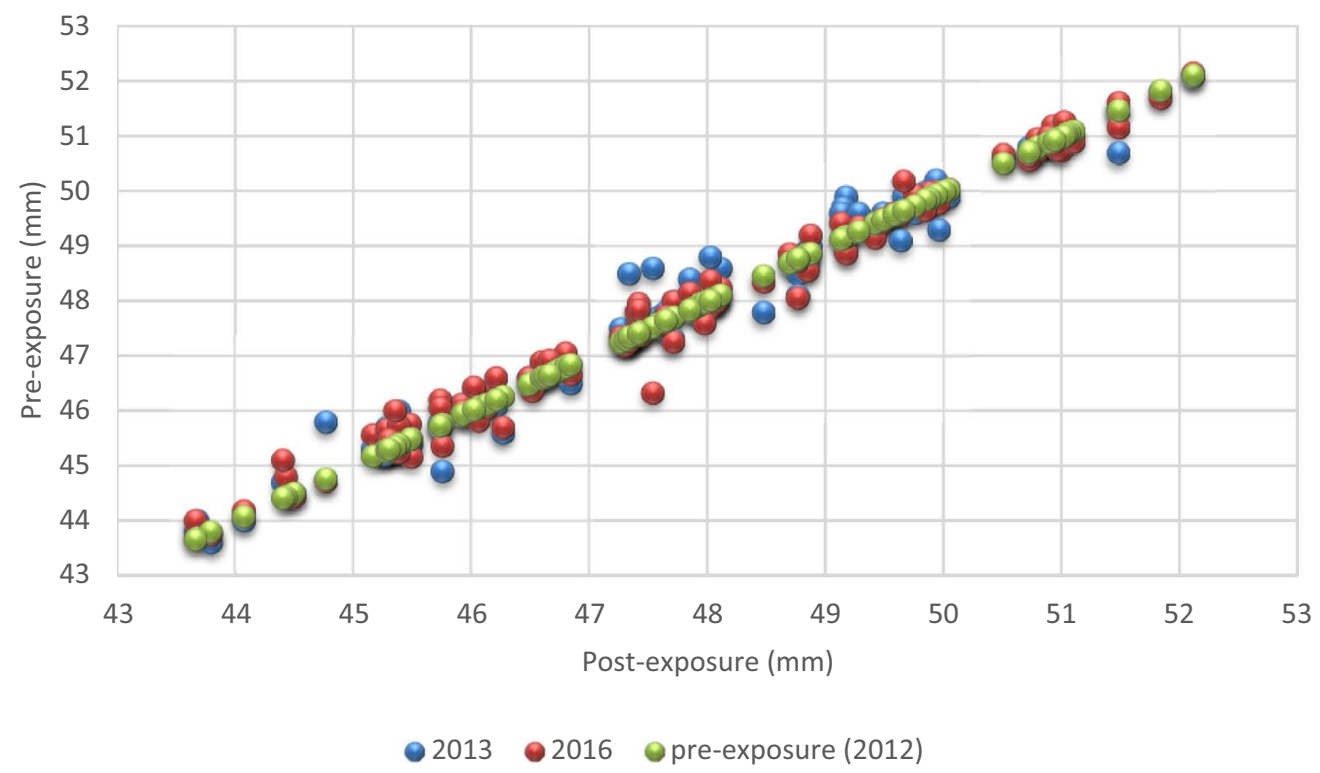

Fig. 9 a, b Deviation of post exposure dimensional measurement from pre-exposure values (2011 and 2012) for Skellig Michael and Brú na Bóinne 
or if surface roughness is more important to partially or completely treat the cubes with biocides.

The pilot study has allowed the initial design to be evaluated. The recommendation for future applications is not to include concrete and brick, but to use two cubes each of Peakmoor and Portland as these produced the most useful comparative data sets, together with the site specific stone. Given the issues with stress cracks a low impact diamond core drill or similar should be used for embedding the fixing system in future.

The central concept of the LegIT is to have long-term continuous exposure of the same cubes, capturing cumulative deterioration. The possible alternative approach would be to periodically replace the cubes thereby building comparative datasets over time from consecutive short-term exposures of fresh stone. While this does not fit within the original Legacy concept it may be a useful approach for some sites to take if there are the resources required to maintain it.

The LegIT is currently utilizable as a practical management aid, an indicator for understanding deterioration and planning conservation treatments. Attribution of observed deterioration to individual environmental parameters, and subsequently to climate change, is not currently possible. Site specific environmental data (climate and air quality) would be necessary to determine the exact conditions that lead to specific mechanisms of surface change, such as biological colonization. Extending the study to locations where such data is available is one future possibility. To increase the robustness of the method and ultimately widen the application of results beyond individual sites, a more statistically relevant trial would need to be developed. This could be achieved by increasing the number of samples while simultaneously reducing the number of materials (maximum two stone types) and other variables (i.e. location and aspect). It is hoped that this pilot trial may serve as a jumping off point for those interested in further developing on the legacy indicator concept.

\section{Conclusion}

Consideration of the results from the 5 year pilot trial of the LegIT has allowed a preliminary evaluation of its potential as a long term indicator for surface weathering. Recommendations have been made for modifications to the design, manufacture and implementation of the tool. Experience from the Rock of Cashel and Dublin Castle illustrate the importance of transferring responsibility from external researchers to those permanently in place, and embedding the LegIT into local management systems. The careful choice of location for installing the plates is also essential to reduce the problem of human interference. The lack of site specific climate and air quality data is noted as a limitation in terms of being able to analyze causality. The methodological questions regarding how best to continue measuring the effects over time and how to interpret these in relation to climate change remain challenging. Nonetheless, the LegIT has provided a clear indication of regional and localized weathering trends, information which can already begin to aid managers in understanding risks and setting priorities-both for further monitoring and for conservation interventions.

\section{Acknowledgements \\ I owe my thanks to the many people that helped with the design, manufac- ture, installation and evaluation of the LegIT and to Lynda Skipper for her com- ments on this article. Special thanks are due to the OPW staff working at the sites of Brú na Bóinne, Clonmacnoise, Dublin Castle, Rock of Cashel and Skellig Michael. I would also like to acknowledge the financial support of University of Lincoln's Research Resources Allocation Fund, without which the 2016 fieldwork phase of the project would not have been possible. Lastly to the anonymous peer-reviewers whose comments helped to improve this article and whose suggestions for future research have been incorporated.}

\section{Authors' contributions}

The author read and approved the final manuscript.

\section{Authors' information}

Information on the author's professional background and research can be found at drcathydaly.com.

\section{Funding}

This research was partially funded by the University of Lincoln from the internal Research Resources Allocation Fund.

\section{Availability of data and materials}

The datasets generated and/or analysed during the current study are not publicly available but are available from the corresponding author on reasonable request.

\section{Competing interests}

The author declares that they have no competing interests.

Received: 4 February 2019 Accepted: 6 May 2019

Published online: 17 May 2019

\section{References}

1. Viles HA. Implications of future climate change for stone deterioration. In: Siegesmund S, Weiss T, Vollbrecht A, editors. Natural stone weathering phenomena, conservation strategies and case studies, vol. 205. London: Geological Society; 2002. p. 407-18.

2. Brimblecombe P. Monitoring the Future. In: Lefevre RA, Sabbioni C, editors. Vulnerability of Cultural Heritage to Climate Change. Bari: Edipuglia; 2010. p. 65-70

3. Daly C, Cox P, Cuffe-Fitzgerald A, Dubs B, Pickerill T. Monitoring impacts of climate change on built heritage. Report for the department of environment heritage and local government by ICOMOS Ireland; 2010. http:// www.icomosireland.ie. Accessed 15 Jan 2016.

4. Haugen A, Bertolin C, Leijonhufvud G, Olstad T, Brostrom T. A methodology for long-term monitoring of climate change impacts on historic buildings. Geosciences. 2018;8:370.

5. Daly C. The design of a legacy indicator tool for measuring climate change related impacts on built heritage. Heritage Science. 2016;4:19.

6. Sabbioni C, Bonazza A. How mapping climate change for cultural heritage? The Noah's Ark project. In: Lefevre RA, Sabbioni C, editors. Climate change and cultural heritage. Bari: Edipuglia; 2010. p. 37-41.

7. Adamson C S, McCabe S, McAllister D, Smith B J, Warke P A. Mapping the spatial distribution of precipitation, biological soiling and decay on 
monuments in Northern Ireland: towards understanding long-term stone response to moisture. Congress of the Carpathian Balkan Geological Association. Thessaloniki: Greece. 2010;99:183-90.

8. Cutler NA, Viles HA, Ahmad S, McCabe S, Smith BJ. Algal 'greening' and the conservation of stone heritage structures. Sci Total Environ. 2013;442:152-64.

9. Charola, A E, Grissom, C, Erder, E, Wachowiak, M J, and Oursler, D. Measuring surface roughness: three techniques. 8th International Congress on Deterioration and Conservation of Stone. Berlin; 1996. p. 1421-34.

10. Kotoula E. Personal communication. Lincoln: University of Lincoln; 2018.

11. Grissom CA, Charola AE, Wachowiak MJ. Measuring Surface roughness on stone: back to basics. Stud Conserv. 2000;45:73-84.

12. Moses C, Robinson D, Barlow J. Methods for measuring rock surface weathering and erosion: a critical review. Earth Sci Rev. 2014;135:141-61.

13. Alwaal AH, Barnett S, Inkpen R, Hastewell L. Monitoring historic concrete and associated cementitious repair-a case study of Boathouse 4, Portsmouth Historic Dockyard, UK. Sixth International Conference on the Durability of Concrete Structures. University of Leeds. 2018. https://www. researchgate.net/publication/326589452. Accessed 8 Oct 2018.

14. Wilhelm K, Viles H, Burke O, Mayaud J. Surface hardness as a proxy for weathering behaviour of limestone heritage: a case study on dated headstones on the Isle of Portland, UK. Environ Earth Sci. 2016;75:1-16.

15. Young ME, Urquhart D. Algal and non-algal soiling rates of some Scottish building sandstones. In: Jones MS, Wakefield RD, editors. Stone weathering and atmospheric pollution network 97: aspects of stone weathering decay and conservation. London: Imperial College Press; 1998. p. 114-24.
16. Adamson C, McCabe S, Warke PA, McAllister D, Smith BJ. The influence of aspect on the biological colonization of stone in Northern Ireland. Int Biodeterior Biodegradation. 2013:84:357-66.

17. Konica Minolta: Precise Color Communication. Konica Minolta Sensing Inc. 2003.

18. McCabe S, Smith BJ, Adamson C, Mullan D, McAllister D. The, "Greening" of natural stone buildings: quartz sandstone performance as a secondary indicator of climate change in the british Isles? Atmos Clim Sci. 2011:1:165-71.

19. Sancho LG, Green ATG, Pintado A. Slowest to fastest: extreme range in lichen growth rates supports their use as an indicator of climate change in Antarctica. Flora. 2007;202:667-73.

20. Met Éireann. Irish National Meteorological Service. http://www.met.ie. Accessed 10 Dec 2018.

21. Perry TD IV, McNamara CJ, Mitchell R. Biodeterioration of stone. Scientific examination of art: modern techniques in conservation and analysis. Washington DC: The National Academies Press; 2005. p. 72-84.

22. Baedecker PA, Reddy MM. The erosion of carbonate stone by acid rain. J Chem Educ. 1993;70:104-8.

23. Viles HA, Taylor MP, Yates TJS, Massey SW. Soiling and decay of N.M.E.P. limestone tablets. Sci Total Environ. 2002;292:215-29.

\section{Publisher's Note}

Springer Nature remains neutral with regard to jurisdictional claims in published maps and institutional affiliations.

\section{Submit your manuscript to a SpringerOpen ${ }^{\circ}$ journal and benefit from:}

- Convenient online submission

- Rigorous peer review

- Open access: articles freely available online

- High visibility within the field

- Retaining the copyright to your article

Submit your next manuscript at springeropen.com 